\title{
THE PRODUCTIVE AND REPRODUCTIVE EFFICIENCY OF THE PREGNANT HEIFERS, MILKED AND SUCKLEDBALADI COWS UNDER DIFFERENT LEVELS OF NUTRITION
}

\author{
A.M. Abd El-Hafeez; M.A.E. Ali;A.A.S. Mahgoub; M. Y. Mohamed and S.A. Ibrahim \\ Animal Production Research Institute, Agricultural Research Center, Dokki, Giza, Egypt.
}

SUMMARY

\begin{abstract}
$\mathrm{T}$ wenty four pregnant Baladi heifers were used to investigate the effects of three varying feed recommendations during pregnancy and lactation periods on subsequent growth, production and reproduction performances. During pregnancy the heifers were randomly distributed among three experimental groups of eight animals each. Heifers were allotted to receive $\left(\mathrm{G}_{1}\right), 100 \%$ of National Research Council (NRC), $100 \%$ and $120 \%$ of Shehata allowances for $\mathrm{G}_{2}$ and $\mathrm{G}_{3}$, respectively. After parturition each group was divided into equal two sub-groups, milking and suckling, four cows for each sub-group. Animals were group-fed their respective diets in six adjacent separate open shaded yard and observed for reproduction behavior. The total DM intake by lactating Baladi cows followed the opposite trend as that DM intake by pregnant Baladi heifers. The higher of serum glucose was affected by dietary energy of pregnant heifers inG 2 and $G_{3}$ than this of $G_{1}$ value. No significant differences were showed in serum glucose values between suckled and milked cows. The values of total serum protein, globulin and A/G ratio were not significantly different among groups. While, serum albumin affected by levels of TDN and DCP groups. Values of serum cholesterol of pregnant heifers fed low energy and protein $\left(\mathrm{G}_{1}\right)$ significantly decreased compared with heifers fed high energy and protein $\left(\mathrm{G}_{2}\right.$ and $\left.\mathrm{G}_{3}\right)$. However, cholesterol values of blood serum in lactating Baladi cows whose calves were reared artificially did not differ from cows suckling their own calf. $\mathrm{T}_{3}$ and $\mathrm{T}_{4}$ values of pregnant heifers are proportionally correlated with the levels of TDN and DCP. In addition, concentrations of $\mathrm{T}_{3}$ and $\mathrm{T}_{4}$ were not affected by milk removal systems. Prolactin concentration of lactating Baladi cows has a positive correlation with the dietary TDN and DCP and there was no significant difference between milked or suckled cows under the same level of nutrition. The average of body weight (ABW) of $\mathrm{G}_{3}$ through pregnancy period were significantly $(P<0.05)$ higher than that of $\mathrm{G}_{1}$ and $\mathrm{G}_{2}$. The average body gain $(A B G)$ and average daily gain $(A D G)$ of cows in $G_{2}$ and $G_{3}$ were significantly $(P<0.05)$ greater than those of $\mathrm{G}_{1}$. However, $A B W$ of $\mathrm{G}_{3}$ through lactation period recorded the highest one followed by $\mathrm{G}_{1}$ then $\mathrm{G}_{2}$. ABW and ADG at the end of lactation period were not affected by milk removal system. Body weight, loss body weight after calving and calves weight of Baladi cows affected by the level of nutrition. Milk production and lactation period of Baladi cows in the $100 \%$ NRC group was highest, followed by cows in the $120 \%$ Shehata group, however cows in the $100 \%$ Shehata group was the lowest. The data showed that plan of nutrition or milk removal system did not affect milk fat, protein and lactose percentages. The mean of somatic cell count was significantly lower in the suckled cows especially in $\mathrm{G}_{2}$ than in milked cows under the same level of nutrition. Superiority of milked or suckled cows fed $100 \%$ Shehata allowances in the reproductive performance compared to other groups. From economical point of view use of $\mathrm{G}_{2}$ under the suckling system could be recommended to improve the productive and reproductive performance of lactating Baladi cows.
\end{abstract}

Keywords: Lactating Baladi cows, productive \& reproduction performance and economic efficiency.

\section{INTRODUCTION}

Lactating Baladi cows are considered low yielders and to some extent hard milkers (Hafez et al., 2002). They have specific milking characteristics and behavioral reflexes that need consideration in milking practices. Improving their productivity needs extensive effort, including interacting genetic and environmental factors.

Nutrition has an important role in the productive and reproductive performance of cattle. Energy is the major nutrient required by adult cattle and its inadequate intake has a detrimental impact on the performance of female bovine. Nutrition can directly influence the uterine environment through protein intake (Perry et al., 2007). Also, Ali et al. (2014) concluded that the recommendations of Shehata (1972) regarding the TDN, DCP and DM intake were more suitable for the productive and reproductive performance and profit above feeding cost of cow Baladi heifers under Egyptian condition.

Early separation of calves from their dams is a keystone of the modern dairy industry, but there is renewed interest in cow-calf rearing systems in dairy production. Cows that suckle calves had increased 
in the overall milk production (Froberg et al., 2007) and their calves had higher weight gains during the period of suckling than bucket-fed calves (Flower and Weary, 2001) which may improve later milk production and reproductive efficiency (Shamay et al., 2005). The increased milk production of cows suckling a calf may result from hormonal changes in the cow. Bar-Peled et al. (1998) found greater plasma concentrations of growth hormone, prolactin, and IGF, and lower insulin concentrations in suckling cows. Generally, the oxytocin response to suckling was greater than that to milking (Lupoli et $a l ., 2001$ ), and when suckling is ad lib, the cows may have reduced oxytocin and prolactin release at milking (Akers and Lefcourt, 1984). Yet reducing the frequency of suckling may limit the suppressive effects of suckling on milk ejection during machine milking (Lupoli et al., 2001). The milk yield of dairy cows is positively related to milking frequency (Bar-Peled et al., 1998).

Few reports have been published concerning nutrition and its effect on the productive and reproductive efficiency of Baladi cattle of Egypt such as El-Banna et al. (2004) and Ali et al. (2014).

Therefore, the aim of the present study was to investigate the efficacy of the varying feed recommendations on growth of Baladi heifers during pregnancy and interacting with milk removal system, either by milking or suckling on milk production and reproduction performance of Baladi cows in the first season. Also simple economic evaluation of the experimental groups was considered.

\section{MATERIALS AND METHODS}

The present study was carried out at Sids Experimental Station belonging to Animal Production Research Institute, Agriculture Research Center, Ministry of Agriculture, located at Beni Suef Governorate in middle Egypt.

\section{Animals and experimental design:}

Twenty four pregnant cow Baladi heifers were randomly distributed among three experimental groups of eight animals each. Previously and before starting the experiment, animals were received their nutritional requirements according to NRC (1988) in the first group (100\% NRC recommendations, $\left.\mathrm{G}_{1}\right)$, and $100 \%\left(\mathrm{G}_{2}\right)$ and $120 \%\left(\mathrm{G}_{3}\right)$ of Shehata (1972) recommendations of TDN, DCP to cover maintenance and production requirements at 10 months of age with average body weighing of $157 \mathrm{~kg}$ for each group and continued until fertilization.

The measurements for this study started when the pregnancy ensured at 4 months for these heifers and continued after parturition until the end of milking period (about 11 months), using the same above feed recommendations. After parturition each group was divided into equal two sub-groups, milking and suckling, four cows for each sub-group. Animals were group-fed their respective diets in six adjacent separate open shaded yard. Fresh and clean drinking water was ad lib at all times. The chemical composition of feedstuffs (concentrate feed mixture, clover hay, and rice straw) are shown in Table 1. The calculated amounts were divided into two equal parts and offered at 09:00 and 15:00 hrs. Animals body weights were determined once a month till the end of the experiment and feed allowances were altered according to their live body weight changes, pregnancy status and milk production. Cows of each sub-group that milked were left to suckle their calves for three days (the colostrum period), and then were hand-milked completely twice daily at 06:00 and 18:00 hrs and their calves were reared artificially twice daily for 15 weeks. Cows of each sub-group that suckled were left with their calves to suckle twice daily. Suckling was allowed for a controlled 15-min period at 06:00 and 18:00 hrs. Milk production of suckled cows was recorded by weighing calves before and after each suckling $(1 \mathrm{~d} / \mathrm{wk})$ as described by Bogges $e t$ al. (1980). The residual milk in udder was completed milked manually and measured to add on milk quantity of suckling. The suckling calves were left to suckle their dams completely for 15 weeks and after they used to stimulus their dams then were hand-milked completely and recorded twice daily till the end of lactation period. Milk yield of milked cows both morning and evening milking were recorded till the end of lactation period. Weights of suckling and milking calves recorded at birth and then monthly till weaning at 15 weeks of age.

Table (1). Chemical composition of feedstuffs (\% on dry matter basis).

\begin{tabular}{llllllll}
\hline Item & DM & OM & CP & EE & CF & NFE & Ash \\
\hline Concentrate feed mixture & 91.35 & 90.45 & 16.25 & 3.25 & 12.25 & 58.70 & 9.55 \\
Clover hay & 89.58 & 87.72 & 13.36 & 2.56 & 25.09 & 46.71 & 12.28 \\
Rice straw & 89.32 & 84.63 & 3.80 & 1.80 & 33.42 & 45.61 & 15.37 \\
\hline
\end{tabular}




\section{Blood sampling and analysis:}

Blood samples were collected monthly from all animals through gestation period and each day beginning at 21 days after parturition for 30 days to determine concentration of progesterone $\left(\mathrm{P}_{4}\right)$, after that returned monthly until the end of lactation period. Samples were allowed to clot then centrifuged for $15 \mathrm{~min}$ at $3000 \mathrm{rpm}$ for serum separation. Serum was stored at $-20^{\circ} \mathrm{C}$ till the assay time. Serum $\mathrm{P}_{4}$ was assayed by the radioimmunoassay (RIA) using commercial kits provided by Beckman Coulter International SA, Switzerland, according to Kubosik et al. (1984). Total protein and Albumin were determined in blood serum using kits of Diamond Diagnostic, EC Hannover, Germany. Glucose and Cholesterol were quantified in blood serum by using kits of Spinreact, S.A.U. Ctra. Santa Coloma, 7 E-17176 Sant Esteve de Bas (GI) Spain by means of spectrophotometer. Globulin level was calculated as the difference between total protein and albumin. Direct RIA technique was performed for assessment of total serum tri-iodothyronine $\left(\mathrm{T}_{3}\right)$ and thyroxine $\left(\mathrm{T}_{4}\right)$ concentrations. Ready antibody-coated tube kits (Total $\mathrm{T}_{3}$ RIA KIT. REF IM 1699-2013-08-14-IM3287) and (Total T4 RIA KIT. REF IM 1447-2013-08-14-IM3286) were used according to the procedure outlined by the manufacturer. Double-antibody RIA was used to determine concentrations of prolactin described by Lapierre et al. (1990).

\section{Milk sampling and analysis:}

Biweekly, representative milk samples were individually collected after calving till the end of lactation period. Milk samples were preserved immediately after each milking by adding three drops of potassium dichromate (5 ppm). Milk constituents such as fat, protein, lactose, total solids and solids-not fat were determined using Milko-Scan ${ }^{\circledR}$ analyzer (USA), Bently 150, USA. Milk yield was corrected for its fat content using Gaines and Davidson (1923) equation where, FCM in $\mathrm{kg}(4 \%$ fat $)=0.4(\mathrm{~kg}$ milk yield) +15 ( $\mathrm{kg}$ fat yield). Somatic cell counts in milk were determined immediately by using Somatic ${ }^{\circ}$, Bently soma count 150 , USA.

\section{Reproductive performance management:}

Postpartum reproductive parameters standing behavior was considered at the main sign of heat and cows which showed that behavior after 45 days, postpartum was naturally inseminated. The reproductive tract and ovaries were palpated once weekly to determine the time of uterine involution and resumption of ovarian. The interval from parturition to each of: uterine involution (UIP), first ovulation (PPOI), first estrus (PPEI), first service (PPSI), number of services per conception (NSPC), service period (SP), and days open (DO) (fertile, service). In quiet ovulation cases, date of ovulation was determined by subtracting three days from the day at which the blood concentration of progesterone $\left(\mathrm{P}_{4}\right)$ level reached $>1.0 \mathrm{ng} / \mathrm{ml}$ and continued at that level for at least three consecutive samples. Pregnancy was diagnosed applying rectal palpation 60 days after last insemination.

\section{Economic feed efficiency:}

Economic efficiency was calculated considering the price of one $\mathrm{kg}$ (DM basis) of concentrate feed mixture, clover hay and rice straw were LE 2.52, 1.33 and 0.45 , respectively. Price of one-kg cow's milk was LE 3.50.

\section{Statistical analyses:}

Data were statistically analyzed using the general linear model procedure (SAS, 2002). The differences among means were tested using Duncan's Multiple-rang test (Duncan, 1955). Two models were used in statistical analysis the first for pregnant heifers:

\section{Where:}

$$
Y_{i j}=\mu+G_{i}+e_{i j}
$$

$Y_{\mathrm{ij}}=$ an observation

$\mu=$ overall means

$\mathrm{G}_{\mathrm{i}}=$ effect of feed levels $(\mathrm{i}=1,2,3)$

$\mathrm{e}_{\mathrm{ij}}=$ random error

Another statistical model was used for cows:

Where: $\mathrm{Y}_{\mathrm{ijk}}=$ an observation

$$
Y_{i j k}=\mu+G_{i}+M_{j}+G M_{i j}+e_{i j k}
$$

$\mu=$ overall means

$\mathrm{G}_{\mathrm{i}}=$ effect of feed levels $(\mathrm{i}=1,2,3)$

$\mathrm{M}_{\mathrm{j}}=$ effect of milk removal system $(\mathrm{j}=1,2)$

$\mathrm{GM}_{\mathrm{ij}}=$ effect of the interaction between feed levels and milk removal system

$\mathrm{e}_{\mathrm{ijk}}=$ random error 


\section{RESULTS AND DISCUSSION}

\section{A. Performance of pregnant Baladi heifers:}

\section{Daily dry matter intake:}

Dry matter (DM) intake by pregnant Baladi heifers fed on concentrate feed mixture (CFM), clover hay and rice straw is shown in Table 2. Total DM intake $\left(\mathrm{kg} / \mathrm{head} / \mathrm{kg} \mathrm{BW} \mathrm{BW}^{0.75} /\right.$ day) of pregnant Baladi heifers fed $100 \%$ of NRC $\left(G_{1}\right)$ were lower than that in heifers fed $100 \%\left(G_{2}\right)$ or $120 \%\left(G_{3}\right)$ of Shehata allowances. The daily TDN intake ( $\mathrm{kg} / \mathrm{head} /$ day) of $\mathrm{G}_{1}$ was insignificantly lower than that in $\mathrm{G}_{2}$ and both of them were significantly lower $(\mathrm{P}<0.05)$ than that in $\mathrm{G}_{3}$. The TDN $\left(\mathrm{kg} / \mathrm{kg} \mathrm{BW} \mathrm{BW}^{0.75}\right)$ of $\mathrm{G}_{1}$ was significantly lower than those in $G_{2}$, while $G_{2}$ was significantly lower $(P<0.05)$ than that of $G_{3}$. Digestible crude protein $(\mathrm{DCP})\left(\mathrm{kg} / \mathrm{head} /\right.$ day or $\left.\mathrm{kg} / \mathrm{kg} \mathrm{BW} \mathrm{BW}^{0.75}\right)$ of $\mathrm{G}_{1}$ was significantly lower $(\mathrm{P}<0.05)$ than that in $G_{2}$, while those of $G_{2}$ were significantly lower $(P<0.05)$ compared to those of $G_{3}$. This was a reflection of the designed plan of nutrition. The results agreed with that reported by Mosaad and Derar (2009) who reported that daily feed intake was found to be increased with increasing the level of energy.

Table (2). Average daily feed intake of pregnant Baladi heifers fed on three levels of requirements.

\begin{tabular}{|c|c|c|c|}
\hline \multirow{2}{*}{ Item } & \multicolumn{3}{|c|}{ Level of Nutrition } \\
\hline & $\mathrm{G}_{1}$ & $\mathrm{G}_{2}$ & $\mathrm{G}_{3}$ \\
\hline Initial body weight & $354.00 \pm 8.33^{b}$ & $350.50 \pm 5.81^{\mathrm{b}}$ & $363.38 \pm 8.83^{a}$ \\
\hline Concentrate feed mixture & $3.07 \pm 0.16^{b}$ & $3.36 \pm 0.42^{b}$ & $4.33 \pm 0.44^{\mathrm{a}}$ \\
\hline Clover hay & $2.79 \pm 0.20^{b}$ & $3.04 \pm 0.30^{\mathrm{b}}$ & $4.02 \pm 0.39^{\mathrm{a}}$ \\
\hline DM intake $\mathrm{g} / \mathrm{KgW}^{0.75}$ & $105.99 \pm 2.12^{c}$ & $117.27 \pm 3.42^{b}$ & $144.30 \pm 7.40^{\mathrm{a}}$ \\
\hline \multicolumn{4}{|l|}{ Daily feed unit intake: } \\
\hline TDN Kg /h/d & $4.87 \pm 0.23^{b}$ & $5.36 \pm 0.34^{b}$ & $6.81 \pm 0.53^{\mathrm{a}}$ \\
\hline TDN W0.75 & $59.67 \pm 0.99^{c}$ & $66.16 \pm 2.019^{\mathrm{b}}$ & $81.82 \pm 3.51^{\mathrm{a}}$ \\
\hline
\end{tabular}

$a, b$ and $c$ : Means of each row with different superscripts are significantly different $(P<0.05)$.

$G_{1}$, fed $100 \% \mathrm{NRC}, \mathrm{G}_{2}$ and $\mathrm{G}_{3}$ fed $100 \%$ and $120 \%$ of Shehata allowances, respectively.

\section{Metabolite Assays:}

Results of blood serum parameters of the different experimental groups are shown in Table (3). The present data of serum glucose clearly indicated that differences between the cows in $\mathrm{G}_{1}$ and $\mathrm{G}_{3}$ were significant $(\mathrm{P}<0.05)$, While there was no significant differences between cows of $\mathrm{G}_{2}$ and $\mathrm{G}_{1}$ or between cows of $\mathrm{G}_{2}$ and $\mathrm{G}_{3}$.

Table (3). Effect of the experimental diet levels on blood serum parameters and Triiodothyronine $\left(\mathrm{T}_{3}\right)$ and Thyroxine $\left(\mathrm{T}_{4}\right)$ of pregnant Baladi heifers.

\begin{tabular}{lccc}
\hline \multirow{2}{*}{ Item } & \multicolumn{3}{c}{ experimental groups } \\
\cline { 2 - 4 } & $\mathrm{G}_{1}$ & $\mathrm{G}_{2}$ & $\mathrm{G}_{3}$ \\
\hline Glucose $(\mathrm{mg} / \mathrm{dl})$ & $69.69 \pm 17.96^{\mathrm{b}}$ & $79.07 \pm 18.47^{\mathrm{ab}}$ & $82.19 \pm 20.32^{\mathrm{a}}$ \\
Total protein $(\mathrm{g} / \mathrm{dl})$ & $8.17 \pm 1.76$ & $8.72 \pm 1.70$ & $8.68 \pm 1.62$ \\
Albumin $(\mathrm{g} / \mathrm{dl})$ & $4.02 \pm 0.49^{\mathrm{b}}$ & $4.14 \pm 0.36^{\mathrm{ab}}$ & $4.25 \pm 0.41^{\mathrm{a}}$ \\
Globulin $(\mathrm{g} / \mathrm{dl})$ & $4.15 \pm 1.70$ & $4.58 \pm 1.74$ & $4.43 \pm 1.62$ \\
A/G ratio & $0.97 \pm 0.32$ & $0.90 \pm 0.25$ & $0.96 \pm 0.30$ \\
Cholesterol (mg/dl) & $164.69 \pm 56.12^{\mathrm{b}}$ & $171.67 \pm 46.44^{\mathrm{ab}}$ & $184.69 \pm 49.24^{\mathrm{a}}$ \\
Hormone profile: & & & \\
$\mathrm{T}_{3}(\mathrm{nmol} / \mathrm{L})$ & $1.07 \pm 0.19^{\mathrm{b}}$ & $1.17 \pm 0.10^{\mathrm{b}}$ & $1.30 \pm 0.37^{\mathrm{a}}$ \\
$\mathrm{T}_{4}(\mathrm{nmol} / \mathrm{L})$ & $63.82 \pm 11.50^{\mathrm{b}}$ & $67.60 \pm 3.98^{\mathrm{b}}$ & $72.80 \pm 10.82^{\mathrm{a}}$ \\
\hline
\end{tabular}

$a$ and $b$ : Means of each row with different superscripts are significantly different $(P<0.05)$.

$G_{1}$, fed $100 \% \mathrm{NRC}, G_{2}$ and $G_{3}$ fed $100 \%$ and $120 \%$ of Shehata allowances, respectively.

The results showed higher glucose values for $\mathrm{G}_{2}$ and $\mathrm{G}_{3}(79.07$ and $82.19 \mathrm{mg} / \mathrm{dl})$ compared to $\mathrm{G}_{1}$ $(69.69 \mathrm{mg} / \mathrm{dl})$. The higher serum glucose of heifers was affected by dietary energy of $\mathrm{G}_{2}$ and $\mathrm{G}_{3}$ compared 
to $\mathrm{G}_{1}$. Similar results were obtained by Ali et al. (2014) who revealed that serum glucose was significantly $(\mathrm{P}<0.05)$ increased in growing Baladi heifers fed high compared to heifers fed low energy diets. The present values of serum glucose are within the normal values of ruminants (ranged between 74.43 to $83.88 \mathrm{mg} / \mathrm{dl}$.

The values of total serum proteins were not significantly different among treated groups. These findings confirmed the concept of Mosaad and Derar (2009) who reported that energy and protein metabolism are closely intertwined in ruminants. This complex balanced system is further complicated as most of the carbohydrates consumed by ruminants are fermented in the rumen to VFAs and limited glucose is available to absorption. Therefore, glucogenesis is of great importance to ruminants. Propionate is the major source of glucose (27-55\%), and glucogenic amino acids supplies a significant amount $(15-36 \%)$ of the glucogenic materials. The present results are agreed with those obtained with Kholif et al. (2011) who found that the concentration of total protein was not significantly different between buffaloes fed on different levels of energy and protein. Ali (2001) found that serum total protein concentration in Egyptian Baladi cattle ranged between 7.22 to $9.62 \mathrm{gm} / \mathrm{dl}$.

Dietary protein can affect the concentration of albumin (Rowlands et al., 1974). The present data of serum albumin among the different experimental groups (Table 3) clearly indicated that serum albumin affected by levels of TDN and DCP in diets. These results are in contrast with Ibrahim et al. (2005) who found that serum albumin was insignificantly lower in Baladi calves and their crosses bred with Abondance and Tarentaise fed high levels of TDN and DCP compared to those fed low of TDN and DCP levels.

It is of interest to note that serum globulin and $\mathrm{A} / \mathrm{G}$ ratio (Table 3) followed the same trend as that of serum total protein. These results are in accordance with Kholif et al. (2011) who reported that serum globulin was not significantly different between buffaloes fed high energy and protein compared to those fed low of energy and protein levels.

The present results concerning serum cholesterol concentration of pregnant Baladi heifers fed different TDN and DCP requirements presented in (Table 3). The average of cholesterol concentration ranged from 164.69 to $184.69 \mathrm{mg} / \mathrm{dl}$. Concentrations of serum cholesterol of pregnant heifers fed low energy and protein $\left(\mathrm{G}_{1}\right)$ were significantly decreased in comparison with heifers fed high energy and protein levels $\left(\mathrm{G}_{2}\right.$ and $\left.\mathrm{G}_{3}\right)$. These results are in harmony with Schrick et al. (1990) who found that cows fed low energy had lower concentrations of serum cholesterol. The previous results are within the values obtained by Abd El-Hafeez et al. (2014) with lactating cows who found that cholesterol concentrations ranged between $153.33-193.33 \mathrm{mg} / \mathrm{dl}$.

\section{Hormone Assays:}

Mean values of $\mathrm{T}_{3}$ and $\mathrm{T}_{4}$ in blood serum of pregnant Baladi heifers fed different TDN and DCP requirements are shown in Table (3). The data indicated that $T_{3}$ and $T_{4}$ concentrations were significantly $(P<0.05)$ higher in $G_{3}$ than those of $G_{1}$ and $G_{2}$. Values of $T_{3}$ and $T_{4}$ are proportionally correlated with the levels of TDN and DCP. These findings may reflect a good feed utilization, absorption and metabolism for heifers fed high levels of TDN and DCP requirements. Collier et al. (1984) reported that the pituitary thyroid axis is an important physiological factor controlling metabolic processes and milk secretion. Thyroid hormones $\left(\mathrm{T}_{3}\right.$ and $\mathrm{T}_{4}$ ) synergize with other hormones to promote growth and development of the mammary gland and maintenance of lactation.

\section{Growth performance:}

Live body weight, average body gain (ABG) and average daily gain (ADG) of pregnant Baladi heifers as affected by level of nutrition are shown in Table (4). There were marked differences in $A B G$ and $A D G$ at the end of the pregnancy period. The ABG and $A D G$ of $G_{2}$ and $G_{3}$ were greater $(P<0.05)$ than of those of $\mathrm{G}_{1}$.

The overall mean of total $A B G$ and $A D G$ of $G_{2}$ and $G_{3}$ were significantly $(P<0.05)$ greater $(12$ and $37 \%$, respectively) than those of $G_{1}$. This was mainly due to low DM, TDN and DCP intakes by $G_{1}$. The differences between $\mathrm{G}_{2}$ and $\mathrm{G}_{3}$ were significant. These results are in agreement with El-Banna et al. (2004) and Ali et al. (2014) who reported that heifers offered high energy had significantly higher final body weight than those on standard diet.

The values of ADG through pregnancy period of $\mathrm{G}_{1}, \mathrm{G}_{2}$ and $\mathrm{G}_{3}$ were $0.424,0.476$ and 0.581 $\mathrm{kg} /$ day, respectively. Ali et al. (2014) found that the ADG was $0.527,0.563$ and $0.638 \mathrm{~kg}$ in growing heifers fed low (100\% NRC), (100\% of Shehata, 1972 allowances) or high level (120\% of Shehata, 1972 allowances) of nutrition, respectively.

Body weight loss after calving and calves weight of Baladi cows as affected by level of nutrition (Table 4) followed the same trend as that of live body weight at the end of pregnancy. There were significant $(\mathrm{P}<0.05)$ differences in body weight loss and calves birth weight of $\mathrm{G}_{3}$ compared to those of 
$\mathrm{G}_{1}$ and $\mathrm{G}_{2}$. These differences may be related to different intakes levels (Table 2). Cows body weight after calving of $G_{2}$ and $G_{3}$ were greater than that of $G_{1}$, while the differences between $G_{1}$ and $G_{2}$ were not significant. These results agreed with El-Banna et al. (2004) and Ali et al. (2014) who reported that heifers offered high energy and protein had significantly higher final body weight than those offered low energy and protein levels.

Table (4). Effect of level of nutrition on live body weight (BW), average body gain (ABG), and average daily gain (ADG) of Baladi heifers, cows and birth weight of calves.

\begin{tabular}{lccc}
\hline \multirow{2}{*}{ Item } & \multicolumn{3}{c}{ Level of Nutrition } \\
\cline { 2 - 4 } & $\mathrm{G}_{1}$ & $\mathrm{G}_{2}$ & $\mathrm{G}_{3}$ \\
\hline Initial BW at end 4 months of pregnancy & & & \\
$(\mathrm{Kg})$ & $354.00 \pm 8.33^{\mathrm{b}}$ & $350.50 \pm 5.81^{\mathrm{b}}$ & $363.38 \pm 8.83^{\mathrm{a}}$ \\
$\mathrm{BW}$, before calving (Kg) & $417.63 \pm 4.42^{\mathrm{b}}$ & $421.88 \pm 7.15^{\mathrm{b}}$ & $450.50 \pm 5.76^{\mathrm{a}}$ \\
$\mathrm{ABG}(\mathrm{Kg})$ & $63.63 \pm 5.49^{\mathrm{c}}$ & $71.38 \pm 2.95^{\mathrm{b}}$ & $87.12 \pm 4.66^{\mathrm{a}}$ \\
ADG (kg/d) & $0.424 \pm 0.037^{\mathrm{c}}$ & $0.476 \pm 0.020^{\mathrm{b}}$ & $0.581 \pm 0.031^{\mathrm{a}}$ \\
$\mathrm{BW}$, after calving (Kg) & $377.38 \pm 6.45^{\mathrm{b}}$ & $380.25 \pm 7.03^{\mathrm{b}}$ & $405.50 \pm 4.90^{\mathrm{a}}$ \\
Loss (Kg) & $40.25 \pm 3.58^{\mathrm{b}}$ & $41.63 \pm 1.69^{\mathrm{b}}$ & $45.00 \pm 1.07^{\mathrm{a}}$ \\
Birth weight of calves (Kg) & $26.00 \pm 4.04^{\mathrm{b}}$ & $28.75 \pm 1.91 \mathrm{a}^{\mathrm{b}}$ & $31.13 \pm 1.36^{\mathrm{a}}$ \\
\hline
\end{tabular}

$a, b$ and $c:$ Means of each parameter with different superscripts are significantly different $(P<0.05)$.

$G_{1}$, fed $100 \% \mathrm{NRC}, \mathrm{G}_{2}$ and $\mathrm{G}_{3}$ fed $100 \%$ and $120 \%$ of Shehata allowances, respectively.

\section{B. Performance of lactating Baladi cows:}

\section{Daily dry matter intake:}

Dry matter (DM) intake by lactating Baladi cows fed on CFM, clover hay and rice straw is shown in Table (5). Total DM intake ( $\mathrm{kg} / \mathrm{head} / \mathrm{kg} \mathrm{BW}$. $75 /$ day) of lactating Baladi cows fed $100 \%$ of $\mathrm{NRC}\left(\mathrm{G}_{1}\right)$ were significantly higher $(\mathrm{P}<0.05)$ than that in cows fed $100 \%\left(\mathrm{G}_{2}\right)$ and $120 \%\left(\mathrm{G}_{3}\right)$ of Shehata allowances. The daily TDN and DCP intakes $\left(\mathrm{kg} / \mathrm{head} /\right.$ day or $\left.\mathrm{kg} / \mathrm{kg} \mathrm{BW}{ }^{0.75}\right)$ of $\mathrm{G}_{1}$ were significantly higher than those of $\mathrm{G}_{2}$ and $\mathrm{G}_{3}$. Also, TDN and $\mathrm{DCP}$ intakes of $\mathrm{G}_{3}$ was significantly higher $(\mathrm{P}<0.05)$ than those of $\mathrm{G}_{2}$. These results may reflect the variation between NRC and Shehata allowances during pregnancy period compared to lactation period.

The results clearly showed that Baladi cows suckling their own calves recorded significantly higher total DM intake and TDN and DCP intakes ( $\mathrm{kg} / \mathrm{head} /$ day or $\mathrm{kg} / \mathrm{kg} \mathrm{BW} \mathrm{BW}^{0.75}$ ) compared to milking Baladi cows under the same level of nutrition. These findings may be related to superior of suckling cows in milk production compared to milking cows at the same level of nutrition (Table 8). The results agreed with those reported by Little et al. (1991) who reported that daily DM intake was found to be increased with suckled cows compared to milked cows during early lactation.

\section{Metabolite Assays:}

Serum glucose values (Table 6) were significantly $(\mathrm{P}<0.05)$ increased with high TDN and DCP groups $\left(G_{1}\right.$ and $\left.G_{3}\right)$ compared to low TDN and DCP group $\left(G_{2}\right)$, while there was no significant differences between $G_{1}$ and $G_{3}$. The higher glucose was affected by dietary energy of $G_{1}$ and $G_{3}$ compared to $\mathrm{G}_{2}$. Similar results were obtained by Ali et al. (2014) and revealed that serum glucose was significantly increased in Baladi heifers fed high energy diets compared to those fed low energy diets. No significant differences were showed in serum glucose values between suckled cows and milked cows at the same level of dietary energy and protein. The same trend was obtained by Radford et al. (1978) who reported that levels of plasma glucose were similar in both groups of suckling and non-suckling beef cows fed a high quality food for 3 months post-partum.

Data of total serum protein, albumin, and globulin were not significantly different among groups, either alone or interacting with milk removal system (milking or suckling). The present results are in agreement with those obtained with Kholif et al. (2011) who found that the concentration of total proteins, albumin, and globulin were not significantly different between lactating buffaloes that fed on different levels of energy and protein.

The present results concerning cholesterol concentration in blood serum of lactating Baladi cows fed different TDN and DCP requirements interacting with milk removal system (milking or suckling) presented in Table (6). The highest values of serum cholesterol recorded by lactating Baladi cows fed $\mathrm{G}_{1}$ diet followed by cows fed $G_{3}$ then $G_{2}$ diets in connection with the data of DM intake as TDN and DCP (Table 5). These results are in harmony with Mosaad and Derar (2009) who informed that serum levels of cholesterol recorded higher significant values in ewes fed on high diet in comparison with that of the control diet. The data showed that cholesterol concentration in blood serum of lactating Baladi cows 
whose calves were reared artificially did not differ from cows suckling their own calf under the same level of nutrition.

\section{Hormone Assays:}

Mean values of blood serum $\mathrm{T}_{3}, \mathrm{~T}_{4}$ and prolactin in blood serum of lactating Baladi cows fed different TDN and DCP requirements interacting with milk removal system (milking or suckling) are shown in Table (6). The data indicated that blood concentrations of $\mathrm{T}_{3}$ and $\mathrm{T}_{4}$ were not affected by either level of TDN and DCP in diet or milk removal system. The data showed that prolactin concentration of lactating Baladi cows had a positive correlation with the dietary TDN and DCP in the experimental groups, where $\mathrm{G}_{1}$ recorded the highest value of prolactin concentration followed by $\mathrm{G}_{3}$ then $\mathrm{G}_{2}$. There were significant $(P<0.05)$ differences in prolactin concentration for cows of $G_{1}$ compared to those of $G_{2}$ and $G_{3}$. These differences may be related to DM, TDN and DCP intakes (Table 5). Feeding diets that promote increases in plasma glucose may improve the metabolic and endocrine status such as prolactin of cows that have higher milk production in early lactation (Santos, 2008). There was no significant difference between milked or suckled cows under the same level of nutrition. These results are in accordance with DePassille et al. (2008) who reported that prolactin concentrations did not change during udder preparation and there was no difference between the two groups of Holstein cows that were milked twice daily, and that either also suckled calves twice daily after calving or that served as non-suckling controls.

\section{Growth performance:}

Data of body weight (BW) and average daily gain (ADG) of calves and lactating Baladi cows as affected by level of nutrition are shown in Table (7). Baladi cows were marked differences in BW and $A D G$ at the end of the lactation period. The growth rates of cows of $G_{1}$ and $G_{3}$ were greater $(P<0.05)$ than those of $G_{2}$. In addition, $B W$ of $G_{1}$ was significantly $(P<0.05)$ higher than that of $G_{2}$. This superior of $G_{1}$ may be related to the increase in requirements by NRC (1988) through lactation period compared with the pregnancy phase as showed in Tables (2 and 5). These results are in agreement with Lacasse and Block (1993) who informed that BW at the end of gestation and after calving were increased by higher feeding compared with moderate feeding. Also, Ali et al. (2014) reported that heifers offered high energy had significantly higher final BW and ADG than those offered the standard diet. The results showed that BW and ADG at the end of lactation period were not affected by milk removal system, either milking or suckling under the same level of nutrition. However, the opposite trend was obtained by Bar-Peled et al. (1995) who reported that the mean of BW and BCS of cows were affected by frequency of milking (three vs. six times) or suckling three times daily in addition to machine milking three times daily.

Body weight of calves at weaning and $A B G$ were affected by plan of nutrition and milk removal system of cows. The BW and ABG were increased in calves suckled their mothers and increasd with those fed diets contained high TDN and DCP $\left(\mathrm{G}_{1}\right.$ and $\left.\mathrm{G}_{3}\right)$ compared to those fed diets contained low TDN and DCP $\left(\mathrm{G}_{2}\right)$. These results in accordance with Gerrits et al. (1996) who reported that protein-free energy intake markedly affected live weight gain, empty body weight, and protein and fat deposition rates. Empty body weight gains for calves fed the high protein-free energy level were higher than those calves fed the low protein-free energy level. The present data showed that calves suckled their mothers recorded higher weights compared to calves suckled artificially at the same level of nutrition. DePassille et al. (2008) cleared that ADG during the 9-weeks suckling period was greater for suckling calves than for calves suckled artificially. Also, suckled calves had higher weight gains during the period of suckling than bucket fed calves (Flower and Weary, 2001).

\section{Milk production:}

Milk production is shown in Table (8). During the treatment period, greater milk production as daily milk yield, daily $4 \%$ FCM, total milk yield, total $4 \%$ FCM and lactation period of Baladi cows for $\mathrm{G}_{1}$, followed by cows in $\mathrm{G}_{3}$ and that of cows in $\mathrm{G}_{2}$ was the lowest. The superiority of $\mathrm{G}_{1}$ compared with other groups $\left(\mathrm{G}_{2}\right.$ and $\left.\mathrm{G}_{3}\right)$ might be due to that level of dietary TDN in the experimental groups (Table 5). Abdou (2011) revealed that milk production tended to increase as energy level increases. Also, Bar-Peled et al. (1997) informed that the DMI was positively related to milk yield. In addition, high plasma glucose likely elevates milk yield because glucose is required by the mammary gland for the production of milk lactose, the primary determinant of milk volume (Allen and Bradford, 2006). Furthermore, Galactopoietic effect of thyroid hormones (Table 6) is due to their influence on mammary gland metabolism, affecting mammary blood flow, nutrient partitioning and mammary secretion rate (Davis et al., 1988). Also, BarPeled et al. (1995) reported that high milk production associated with elevated prolactin. In the present study, increased prolactin concentrations (Table 6) were associated with increased milk yield (Table 8) and feed intake (Table 5) of lactating Baladi cows. The results showed that daily milk yield and daily $4 \%$ FCM of suckled cows were significantly higher than that of milked cows among the experimental groups 
except for $\mathrm{G}_{3}(\mathrm{P}<0.05)$. Also, total milk yield and total $4 \%$ FCM were following the same trend. In addition, the lactation period in suckled cows numerically increased compared to milked cows in $\mathrm{G}_{1}$ and $\mathrm{G}_{2}$ but the differences between suckled cows and milked cows were significant in $\mathrm{G}_{3}$. This might be due to increasing glucose and prolactin concentrations, which associated with elevated the oxytocin as a result of the unique stimulus of suckling in suckled cows compared with milked cows. Therefore, it is possible that oxytocin is involved in regulating the increase in milk production elicited by suckling, perhaps by allowing for more complete milk removal and a decrease in negative feedback on the gland. Lupoli et al. (2001) reported that oxytocin response to suckling was greater than that to milking. Walsh (1974) suggested that the increase in milk production elicited by suckling was probably due to the additional stimulus of the gland as well as the markedly improved mammary health of suckled animals. These results are in agreement with Bar-Peled et al. (1997) who showed that milk yield of cows in the suckled three times group was further increased compared to those of the six times milked cows group.

The lactation period was longer for cows suckling their own calves compared to those milking that were reported previously by Margerison et al., (2002) who suggested that the lactation length may be influenced by the strength of the bond between the cow and her calf. A more rapid evacuation of the udder of suckled cows through increased oxytocin production as a result of the suckling could also stimulate milk secretion in the long term by remodeling the epithelial cells of the alveoli (Ballou et al., 1993). A long-term effect is believed likely because others have found that milk yield is increased by suckling in the post weaning period (Little et al., 1991). In addition to the increase in milk yield, suckling during early lactation has also been associated with the increase in lactation length (Krohn, 2001).

\section{Milk composition and somatic cell count:}

Results presented in Table (9) showed that there was no significant difference for the contents of fat, protein and lactose among different groups. The data showed that plan of nutrition or milk removal system did not effect milk fat, protein and lactose percentages. The same trend was obtained by Lacasse and Block (1993) who found that fat and protein content of the milk were not affected by the plane of nutrition. However, the milk yield of fat and protein of suckled cows were significantly higher $(\mathrm{P}<0.05)$ than those of milked cows. The obtained results are in agreement with Margerison et al. (2002) who found that the yield of fat and protein was greater for cows suckled by multiple-access calves, less for those suckled by their own calves, and least for those not suckled.

There were differences within the experimental groups in somatic cell count (SCC) that may be linked to milk yield (Table 9). Coulon et al. (1996) informed that the SCC differences may be more linked to milk yield, where low-producing cow contained fewer somatic cells than in higher yielding cows.

The mean SCC was significantly lower in the suckled cows than in the milked cows under the same level of nutrition. The reduction in SCC with suckling supports previous observations that the incidence of mastitis is reduced with suckling (Alvarez et al., 1980 and Teeluck et al., 1981). Suckling cows during early lactation has consistently been associated with a decrease in SCC and a decrease in the incidence of clinical mastitis, in some cases by up to $50 \%$ or more (Krohn, 2001). This is likely to be due to the more efficient evacuation of the udder by the calf than by the milking system, either manual or mechanic, with reduced opportunity for bacterial proliferation in the residual milk.

\section{Reproductive performance:}

The effect of plan of nutrition and milk removal system on reproductive traits, including days of maximum progesterone $\left(\mathrm{P}_{4}\right)$ level (value of maximum $\mathrm{P}_{4}$ level $\mathrm{ng} / \mathrm{ml}$, day to reach $\geq 1.0 \mathrm{ng} / \mathrm{ml}$ ), days from calving to uterine involution period (UIP). Also, first ovulation (PPOI), first estrus (PPEI), first service (PPSI), and service period (SP), days open (DO) and number of services per conception (NS/C) of milked and suckled Baladi cows in the first season and their overall means are shown in Table (10). The present data revealed that days of maximum $\mathrm{P}_{4}$ level were significantly $(\mathrm{P}<0.05)$ shorter in cows fed $100 \%$ Shehata group $\left(\mathrm{G}_{2}\right)$, either milked or suckled cows than those fed $100 \%$ NRC $\left(\mathrm{G}_{1}\right)$ and $120 \%$ Shehata group $\left(\mathrm{G}_{3}\right)$. Similar trend was also observed concerning day to reach $\geq 1.0 \mathrm{ng} / \mathrm{ml}$ where cows fed $\mathrm{G}_{2}$ milked cows diet were significantly $(\mathrm{P}<0.05)$ and suckled cows were insignificantly shorter than $\mathrm{G}_{1}$ and $\mathrm{G}_{3}$. While, value of maximum $\mathrm{P}_{4}$ level was significantly $(\mathrm{P}<0.05)$ increased in $\mathrm{G}_{2}$, either the milked or suckled cows when compared to the same cows of removal system in $G_{1}$ and $G_{3}$. The differences between the suckled and milked cows were not significant in $\mathrm{G}_{1}$ and significant in $\mathrm{G}_{2}$ and $\mathrm{G}_{3}$. The overall mean of uterine involution period (UIP) was shorter $(\mathrm{P}<0.05)$ in $\mathrm{G}_{2}$ cows, either milked or suckled as compared to cows in $\mathrm{G}_{1}$ and $\mathrm{G}_{3}$. Similar trend was observed concerning PPOI where cows of $\mathrm{G}_{2}$ resumed their ovarian activity post-partum earlier than those of $\mathrm{G}_{1}$ and $\mathrm{G}_{3}$. The interesting point to be noted is that most cows displayed their first ovulation within one-month post-partum. Moreover, the obtained PPEI and PPSI by cows of $G_{2}$ were significantly $(P<0.05)$ shorter than those others in $G_{1}$ and $G_{3}$. It is worth to note that cows of $\mathrm{G}_{2}$ resulted in shorter $(\mathrm{P}<0.05) \mathrm{SP}$ and $\mathrm{DO}$, and required less services to get pregnant 
(Table 10), relative to other groups. Such findings indicating the superiority of milked or suckled cows of $\mathrm{G}_{2}$ in the reproductive status that may be related to the opposite mutual effect of nutrition (Table 5) and milk production (Table 8 ) as indicated by Butler (2000) who reported that increased capability for milk production has been associated with a decline in fertility of lactating cows. Nutritional requirements increase rapidly with increasing milk production after calving and delays the time of first ovulation through inhibition of LH pulse frequency and low levels of blood insulin and insulin-like growth factor-I (IGF-I) that collectively restrain estrogen production by dominant follicles. Up-regulation of LH pulses and peripheral IGF-I in association with nadir facilitates ovulation. Diets high in crude protein support high milk yield, but are also associated with lower reproductive performance. Also, high protein intake can result in elevated plasma urea concentrations that affect the uterine environment and fertility. In addition, the decreasing level of serum cholesterol of $\mathrm{G}_{2}$ cows that fed $100 \%$ shehata allowances (Table 6) compared to other groups may be attributed to the increasing demand of cholesterol in the biosynthesis of the steroid hormones towards the sexual maturity since about $25 \%$ of daily-formed cholesterol is used in the synthesis of steroid hormones (Sommer, 1969). The present data showed that there were no significant differences between milked and suckled cows among the experimental groups in some of reproductive traits and sometimes the differences were significant $(\mathrm{P}<0.05)$ in other some of reproductive traits. Consequently, the effects of suckling on reproductive performance appear to be negative or in some cases positive (Table 10). An interesting study conducted by Bar-Peled et al. (1997) reported on the performance of first lactation heifers that were allowed to suckle their calves, and compared them to heifers that were reared on milk replacer. Their findings have major implications regarding the effects of suckling on performance as adults; suckling clearly improved production efficiency, body weight at conception, age at conception, conception rate and services per conception. In addition, Perez-Hernandez et al. (2002) reported that exposure of cows to a teaser bull decreased the effects of suckling on days to first estrus. Therefore, in agreement with the suggestion by Armstrong et al. (1985), simple changes in management when feasible can be used to overcome any potential negative impact of suckling regime on reproductive performance.

Finally, the present results indicated that feeding on $100 \%$ shehata allowances $\left(\mathrm{G}_{2}\right)$ especially under the suckling system improved the productive and reproductive performances compared to other groups.

\section{Economic evaluation:}

Economic evaluation of the experimental groups presented in Table (11). The profit above feeding cost was highest with suckled cows fed $100 \%$ of Shehata (1972) recommendations of TDN, DCP and DM intake followed by suckled cows that fed $100 \%$ NRC, while the milked cows that fed $120 \%$ Shehata (1972) recommendations recorded the lowest one. Our results illustrated that the superiority of suckled cows that fed $100 \%$ of Shehata (1972) recommendations of TDN, DCP and DM intake comes from the increasing of profit above feeding cost during lactation period compared to other groups, although they have lowered lactation period but this possible is better to prepare it early to the next season. These results are in accordance with McKusick et al. (2001) who estimated an increase in net income of $\$ 25$ per ewe/suckling lamb pair in a mixed rearing system (in which ewes are suckled and machine milked until lambs are weaned) relative to ewes solely machine milked and lambs raised on milk replacer. In addition, the increase in profitability of suckling management systems comes from eliminating the expenses associated with purchase of milk replacer, and also the increase in milk production of the dams after the suckling period. This combined with the observation of Bar-Peled et al. (1997) that suckling calves perform better got adults, indicates multiple areas of economic gain with a suckling regime. Therefore, when there are no negative effects on animal health or reproductive performance, suckling has the potential to be profitable management tool.

\section{CONCLUSION}

In conclusion, Shehata (1972) recommendations of TDN, DCP and DM intake were more suitable to the productive and reproductive performance, and profit above feeding cost of lactating Baladi cows under Egyptian condition. Also, suckling system has the potential to be profitable management tool. 


\section{REFERENCES}

Abd El-Hafeez, A. M.; M.Y. Mohamed; A.A.S. Mahgoub; M.A. Ahmed; M.K. El-Banna and S.M. Zahed (2014). Evaluating the cross-breeding of Baladi cows and their crossbreds with French abondance and tarentaise breeds through studying the production potential, milk quality and its products. J. Egypt. Vet. Med. Asso., 74(3):493.

Abdou, A.R. (2011). Effect of energy level on digestion coefficients and performance of ewes during pregnancy and lactation in southern Sinai. Egyptian J. Nutrition and Feeds, 14 (3): 349.

Akers, R.M. and A.M. Lefcourt (1984). Effects of presence of calf on milking-induced release of prolactin and oxytocin during early lactation of dairy cows. J. Dairy Sci., 67:115.

Ali, M.A.E. (2001). Effect of climatic changes on the physiological and productive performance in cattle under the conditions of north of Nile Delta. M. Sc. Thesis, Faculty of Agriculture, Cairo University, Egypt.

Ali, M.A.E.; A.M. Abd El-Hafeez S.A. Ibrahim and Safaa N. Abd El-Azem (2014). The productive and reproductive efficiency of cow Baladi heifers under different levels of nutrition. Egyptian J. Nutrition and Feeds, 17(1): 51.

Allen, M.S. and B. J. Bradford (2006). From the liver to the brain: increasing feed intake in transition cows. pp. 115-124. Proc. 68th Meeting of the Cornell Nutrition Conference for Feed Manufacturers, Department of Animal Science, Cornell University, Ithaca, NY 14850.

Alvarez, F.J.; G. Saucedo; A. Arriaga and T.R. Preston (1980). Effect on milk production and calf performance of milking cross bred European/zebu cattle in the absence or presence of the calf, and of rearing their calves artificially. Trop. Anim. Prod. 5(1):25.

Armstrong, D.V.; R. Selley and D.L. Bath (1985). Three times a day milking. National Cooperative Dairy Herd Improvement Program Fact Sheet No. 1-2. p 1-4.

Ballou, L.U.; J.L. Bleck, G.T. Bleck and R.D. Bremel (1993). The effects of daily oxytocin injections before and after milking on milk production and milk composition. J. Dairy Sci., 76:1544.

Bar-Peled U.; Y. Aharoni; B. Robinzon; I. Bruckental; R. Lehrer; E. Maltz; C. Knight; J. Kali; Y. Folman; H. Voet; H. Gacitua and H. Tagari (1998). The effect of enhanced milk yield of dairy cows by frequent milking or suckling on intake and digestibility of the diet. J. Dairy Sci., 81:1420.

Bar-Peled, U.; B. Robinzon; E. Maltz; H. Tagari; Y. Folman; I. Bruckental; H. Voet; H. Gacitua and A.R. Lehrer (1997). Increased weight gain and effects on production parameters of Holstein heifer calves that were allowed to suckle from birth to six weeks of age. J. Dairy Sci., 80: 2523.

Bar-Peled, U.; E. Maltz; I. Bruckental; Y. Folman; Y. Kali; H. Gacttua and A.R. Lehrer (1995). Relationship between frequent milking or suckling in early lactation and milk production of high producing dairy cows. J. Dairy Sci., 78: 2726.

Bogges, D.L.; E.F. Smith; R.R. Schalles; B.E. Brent; L.R. Corah and R.J. Pruitt (1980). Effects of milk and forage intake on calf performance. J. Anim. Sci., 51:550.

Butler, W.R. (2000). Nutritional interactions with reproductive performance in dairy cattle. Anim. Reprod. Sci., 60-61: 449.

Collier, R.J.; J.P. McNamara; C.R. Wallace and M.H. Dehoff (1984). A review of endocrine regulation of metabolism during lactation. J. Anim. Sci., 59:498.

Coulon. J.B; F. Bauver and J.P. Garel (1996). Facteurs de variation de la numeration cellulaire du lait chez des vaches laitieres indemnes de mammites Clinique, INRA Prod. Anim., 9 (1): 23.

Davis, S.R.; R.J. Collier; J.P. McNamara; H.H. Head; W.J. Croom and C.J. Wilcox (1988). Effect of thyroxin and growth hormone treatment of dairy cows on mammary uptake of glucose, oxygen and other milk fat precursors. J. Anim. Sci., 66:80.

DePassille, A.M.; P.G. Marnet; H. Lapierre and J. Rushen (2008). Effects of twice-daily nursing on milk ejection and milk yield during nursing and milking in dairy cows. J. Dairy Sci., 91:1416.

Duncan, D.B. (1955). Multiple ranges and multiple F. Test. Biometrics, 11: 1.

El-Banna, M.K; S.A. Ibrahim; H.M. Shabrawy and E.R. El-Sedfy (2004). Relationships among plan of nutrition, weight gain, age at puberty and reproductive performance in Baladi Heifers. J. Agric. Sci. Mansoura Univ., 29: 1091.

Flower, F.C. and D.M. Weary (2001). Effects of early separation on the dairy cow and calf: 2. Separation at 1 day and 2 weeks after birth. Appl. Anim. Behav. Sci., 70:275.

Froberg, S.; A. Aspegren-Guldorff; I. Olsson; B. Marin; C. Berg; C. Hernandez; C.S. Galina; L. Lidfors and K. Svennersten-Sjaunja ( 2007). Effect of restricted suckling on milk yield, milk composition and udder health in cows and behaviour and weight gain in calves, in dual-purpose cattle in the tropics. Trop. Anim. Health Prod., 39:71. 
Gaines, W.L. and F.A. Davidson (1923). Relation between percentage fat content and yield of milk: Correction of milk yield for fat content. University of Illinois, Agricultural Experiment Station, Bulletin, 245:577.

Gerrits, W.J.J.; G.H. Tolman; J.W. Schrama; S. Tamminga; M.W. Bosch and M.W.A. Verstegen (1996). Effect of protein and protein-free energy intake on protein and fat deposition rates in pre-ruminant calves of 80 to $240 \mathrm{~kg}$ live weight. J. Anim. Sci., 74:2129.

Hafez, Y.M.; A.M. El-Gaafarawy; Z.H. Rabie and M.K. El Bana (2002). Effect of oxytocin administration on milking characteristics and some physiological responses of Baladi cows. J. Agric. Sci. Mansoura Univ., 27:1441.

Ibrahim, S.; A.M. El-Gaafarawy; S.M. El-Sheikh; Hanaa, A. El-Koussy and S.A. Swiefy (2005). Feeding and meat production-related parameters in Baladi, Abondancex Baladi and Tarentaise $\times$ Baladi fattened calves. Proc. 2nd Conf. Anim. Prod. Res. Inst., Sakha 27-29 Sep.: 107.

Kholif, S.M.; T.A. Morsy; A.A. Abedo; N. El-Bordeny and M.M. Abdo (2011). Milk production and composition, milk fatty acid profile, nutrients digestibility and blood composition of dairy buffaloes fed crushed flaxseed in early lactation. Egyptian J. Nutrition and Feeds, 14 (3): 409.

Krohn, C.C. (2001). Effects of different suckling systems on milk production, udder health, reproduction, calf growth and some behavioural aspects in high producing dairy cows - a review. Appl. Anim. Behav. Sci., 72(3): 271.

Kubosik, N.P.; G.D. Hallauer and R.G. Brodows (1984). Evaluation of a direct solid-phase radioimmunoassay for progesterone, useful for monitoring luteal function. Clin. Chem., 30 (2): 284

Lacasse, P. and E. Block (1993). Effect of plane of nutrition of dairy heifers before and during gestation on milk production, reproduction, and health. J. Dairy Sci., 76:3420.

Lapierre, H.; G. Pellitclerc; D. Petitclerc; P. Dubreuil; J. Morisset; P. Gaudreau; Y. Couture and P. Brazeau (1990). Effect of human growth hormone releasing factor and (or) thyrotropin-releasing factor on hormone concentrations and milk production in dairy cows. Can. J. Anim. Sci., 70:175.

Little, D.A.; F.M. Anderson and J.W. Durkin (1991). Influence of partial suckling of crossbred dairy cows on milk offtake and calf growth in the Ethiopian highlands. Trop. Anim. Health Prod., 23:108.

Lupoli, B.; B. Johansson; K. Uvnas-Moberg and K. Svennersten-Sjaunja (2001). Effect of suckling on the release of oxytocin, prolactin, cortisol, gastrin, cholecystokinin, somatostatin and insulin in dairy cows and their calves. J. Dairy Res., 68:175.

Margerison, J.K.; T.R. Preston and C.J.C. Phillips (2002). Restricted suckling of tropical dairy cows by their own calf or other cows' calves. J. Anim. Sci., 80:1663.

McKusick, B.C.; D.L. Thomas and Y.M. Berger (2001). Effect of weaning system on commercial milk production and lamb growth of East Friesian dairy sheep. J. Dairy Sci., 84: 1660.

Mosaad G.M. and D.R. Derar (2009). Effect of dietary energy and phosphorus on nutrients digestibility, blood constituents, and ovarian structures in ewes. Veterinary World, 2(12): 456.

NRC (1988). Nutrient Requirements of Dairy Cattle (6th Ed.). National Academy Press, Washington, DC.

Perez-Hernandez, P.; M. Garcia-Winder and J. Gallegos-Sanchez (2002). Bull exposure and an increased within-day milking to suckling interval reduced postpartum anoestrus in dual purpose cows. Anim. Reprod. Sci., 74: 111

Perry, G.; B. Perry; J. Nelson; J. Walker and C. Wright (2007). Influence of post-AI nutrition on blood urea nitrogen, progesterone, and pregnancy. Dep. of Anim. and Range Sciences. BEEF2007-05:25.

Radford, H. M.; C.D. Nancarrow and P.E. Mattner (1978). Ovarian function in suckling and non-suckling beef cows post-partum. J. Reprod. Fertil., 54: 49.

Rowlands, G.J.; W. Little; R. Manston and S.A. Dew (1974). The effect of season on the composition of the blood of lactating and non-lactating cows as revealed from reported metabolic profile test on 24 dairy herds. J. Agric. Sci., 83: 27.

Santos, J.E.P. (2008). Impact of nutrition on dairy cattle reproduction. High Plains Dairy Conference, Albuquerque, (USA), pp. 25-36.

SAS (2002). User's Guide: Statistics, Version 9.0 Edition. SAS Institute Inc., Cary, NC, USA.

Schrick, F.N.; J.C. Spitzer; T.C. Jenkins; D.M. Henricks and T.G. Althen (1990). Effect of dietary energy restriction on metabolic and endocrine responses during the estrous cycle of the suckled beef cow. J. Anim. Sci., 68:3313.

Shamay, A.; D. Werner; U. Moallem; H. Barash and I. Bruckental (2005). Effect of nursing management and skeletal size at weaning on puberty, skeletal growth rate, and milk production during first lactation of dairy heifers. J. Dairy Sci., 88:1460.

Shehata, O. (1972). Lectures in Animal Production. Fac. Agric. Ain Shams University, (in Arabic).

Sommer, H. (1969). Zuruber washing der gesundhiet des Rinds mithilfgeKlinishchemicher. Untersuch. Arch. Ezper. Med. Ed. 24. H. 3: 735. 


\section{Abd El-Hafeez et al.}

Teeluck, J.P.; B. Hulman and T.R. Preston (1981). Effect of milking frequency in combination with restricted suckling on milk yield and calf performance. Trop. Anim. Prod., 6: 138.

Walsh, J.P. (1974). Milk secretion in machine-milked and suckled cows. Ir. J. Agric. Res., 13: 77. 
Table (5). Average daily feed intake of milking and suckling Baladi cows fed on three levels of requirements.

\begin{tabular}{|c|c|c|c|c|c|c|}
\hline \multirow{3}{*}{ Item } & \multicolumn{6}{|c|}{ Level of Nutrition } \\
\hline & \multicolumn{2}{|c|}{$\mathrm{G}_{1}$} & \multicolumn{2}{|c|}{$\mathrm{G}_{2}$} & \multicolumn{2}{|c|}{$\mathrm{G}_{3}$} \\
\hline & Milking & Suckling & Milking & Suckling & Milking & Suckling \\
\hline LBW, at parturition & $377.25 \pm 3.69^{\mathrm{b}}$ & $377.50 \pm 9.13^{\mathrm{b}}$ & $380.50 \pm 8.91^{\mathrm{b}}$ & $380.00 \pm 5.97^{\mathrm{b}}$ & $406.00 \pm 2.38^{\mathrm{a}}$ & $405.00 \pm 7.05^{\mathrm{a}}$ \\
\hline \multicolumn{7}{|l|}{ Daily DM intake $(\mathrm{Kg})$ : } \\
\hline Concentrate feed mixture & $4.53 \pm 0.79^{\mathrm{a}}$ & $4.96 \pm 0.53^{\mathrm{a}}$ & $2.82 \pm 0.11^{\mathrm{c}}$ & $2.73 \pm 0.31^{\mathrm{c}}$ & $3.82 \pm 0.30^{\mathrm{b}}$ & $3.77 \pm 0.40^{\mathrm{b}}$ \\
\hline Clover hay & $2.85 \pm 0.18^{\mathrm{a}}$ & $2.86 \pm 0.16^{\mathrm{a}}$ & $2.08 \pm 0.17^{\mathrm{b}}$ & $2.29 \pm 0.13^{\mathrm{b}}$ & $2.70 \pm 0.23^{\mathrm{a}}$ & $2.96 \pm 0.35^{\mathrm{a}}$ \\
\hline Rice straw & $2.09 \pm 0.52^{\mathrm{bc}}$ & $2.09 \pm 0.50^{\mathrm{bc}}$ & $1.91 \pm 0.18^{\mathrm{c}}$ & $2.43 \pm 0.33^{\mathrm{abc}}$ & $2.82 \pm 0.18^{\mathrm{a}}$ & $2.55 \pm 0.43^{\mathrm{ab}}$ \\
\hline Total DM intake $(\mathrm{Kg} / \mathrm{h} / \mathrm{d})$ & $9.47 \pm 0.38^{\mathrm{a}}$ & $9.91 \pm 0.39^{\mathrm{a}}$ & $6.81 \pm 0.39^{\mathrm{b}}$ & $7.45 \pm 0.74^{\mathrm{b}}$ & $9.34 \pm 0.39^{\mathrm{a}}$ & $9.28 \pm 0.78^{\mathrm{a}}$ \\
\hline DM intake $\mathrm{g} / \mathrm{KgW}^{0.75}$ & $110.63 \pm 6.87^{\mathrm{ab}}$ & $115.72 \pm 6.50^{\mathrm{a}}$ & $79.05 \pm 5.63^{\mathrm{c}}$ & $86.57 \pm 10.15^{\mathrm{c}}$ & $103.26 \pm 5.62^{\mathrm{b}}$ & $102.79 \pm 10.29^{b}$ \\
\hline \multicolumn{7}{|l|}{ Daily feed unit intake: } \\
\hline $\mathrm{TDN} \mathrm{Kg} / \mathrm{h} / \mathrm{d}$ & $5.66 \pm 0.34^{\mathrm{ab}}$ & $5.97 \pm 0.31^{\mathrm{a}}$ & $3.98 \pm 0.21^{\mathrm{c}}$ & $4.27 \pm 0.42^{c}$ & $5.42 \pm 0.23^{b}$ & $5.43 \pm 0.47^{b}$ \\
\hline TDN W $\mathrm{W}^{0.75}$ & $66.12 \pm 5.66^{\mathrm{ab}}$ & $69.71 \pm 5.30^{\mathrm{a}}$ & $46.20 \pm 3.13^{c}$ & $49.62 \pm 5.71^{\mathrm{c}}$ & $59.92 \pm 3.50^{\mathrm{b}}$ & $60.15 \pm 6.40^{\mathrm{b}}$ \\
\hline $\mathrm{DCP} \mathrm{Kg} / \mathrm{h} / \mathrm{d}$ & $0.870 \pm 0.14^{\mathrm{a}}$ & $0.950 \pm 0.10^{\mathrm{a}}$ & $0.550 \pm 0.02^{\mathrm{c}}$ & $0.540 \pm 0.06^{\mathrm{c}}$ & $0.740 \pm 0.05^{\mathrm{b}}$ & $0.740 \pm 0.08^{\mathrm{b}}$ \\
\hline DCP W $W^{0.75}$ & $10.16 \pm 1.86^{a}$ & $11.09 \pm 1.52^{\mathrm{a}}$ & $6.38 \pm 0.38^{c}$ & $6.27 \pm 0.75^{c}$ & $8.18 \pm 0.77^{\mathrm{b}}$ & $8.20 \pm 1.13^{\mathrm{b}}$ \\
\hline
\end{tabular}

$a, b$ and $c:$ Means of each parameter with different superscripts are significantly different $(P<0.05)$.

$G_{1}$, fed $100 \% N R C, G_{2}$ and $G_{3}$ fed $100 \%$ and $120 \%$ of Shehata allowances, respectively.

Table (6). Blood serum parameters of milking and suckling Baladi cows fed on three levels of requirements.

\begin{tabular}{|c|c|c|c|c|c|c|}
\hline \multirow[t]{3}{*}{ Item } & \multicolumn{6}{|c|}{ experimental groups } \\
\hline & \multicolumn{2}{|l|}{$\mathrm{G}_{1}$} & \multicolumn{2}{|c|}{$\mathrm{G}_{2}$} & \multicolumn{2}{|c|}{$\mathrm{G}_{3}$} \\
\hline & Milking & Suckling & Milking & Suckling & Milking & Suckling \\
\hline Glucose (mg/dl) & $81.82 \pm 13.38^{\mathrm{ab}}$ & $87.50 \pm 8.68^{\mathrm{a}}$ & $60.91 \pm 7.98^{c}$ & $68.18 \pm 13.38^{\mathrm{bc}}$ & $76.08 \pm 11.72^{\mathrm{ab}}$ & $78.98 \pm 6.40^{\mathrm{ab}}$ \\
\hline Total protein $(\mathrm{g} / \mathrm{dl})$ & $10.19 \pm 1.06$ & $10.30 \pm 1.00$ & $9.44 \pm 0.79$ & $9.81 \pm 0.31$ & $10.00 \pm 0.92$ & $10.07 \pm 0.90$ \\
\hline Albumin (g/dl) & $4.86 \pm 0.25^{\mathrm{a}}$ & $4.90 \pm 0.24^{\mathrm{a}}$ & $4.38 \pm 0.60^{\mathrm{ab}}$ & $4.67 \pm 0.45^{\mathrm{ab}}$ & $4.62 \pm 0.48^{\mathrm{ab}}$ & $4.26 \pm 0.27^{b}$ \\
\hline Globulin (g/dl) & $5.33 \pm 0.85$ & $5.40 \pm 1.00$ & $5.06 \pm 1.19$ & $5.15 \pm 0.50$ & $5.38 \pm 1.05$ & $5.81 \pm 0.92$ \\
\hline $\mathrm{A} / \mathrm{G}$ ratio & $0.91 \pm 0.11$ & $0.91 \pm 0.16$ & $0.87 \pm 0.28$ & $0.91 \pm 0.17$ & $0.86 \pm 0.23$ & $0.73 \pm 0.14$ \\
\hline Cholesterol (mg/dl) & $193.48 \pm 44.55^{\mathrm{a}}$ & $195.65 \pm 36.30^{\mathrm{a}}$ & $130.43 \pm 7.10^{\mathrm{b}}$ & $134.78 \pm 51.44^{\mathrm{b}}$ & $142.79 \pm 24.65^{b}$ & $152.17 \pm 35.40^{\mathrm{b}}$ \\
\hline $\mathrm{T}_{3}(\mathrm{nmol} / \mathrm{L})$ & $1.39 \pm 0.73^{\mathrm{ab}}$ & $1.89 \pm 0.04^{\mathrm{a}}$ & $1.17 \pm 0.12^{\mathrm{b}}$ & $1.23 \pm 0.55^{\mathrm{ab}}$ & $1.30 \pm 0.22^{\mathrm{ab}}$ & $1.36 \pm 0.55^{\mathrm{ab}}$ \\
\hline $\mathrm{T}_{4}(\mathrm{nmol} / \mathrm{L})$ & $75.53 \pm 14.05^{\mathrm{a}}$ & $76.07 \pm 1.22^{\mathrm{a}}$ & $60.85 \pm 1.23^{\mathrm{b}}$ & $63.30 \pm 10.08^{\mathrm{ab}}$ & $63.89 \pm 2.71^{\mathrm{ab}}$ & $64.55 \pm 12.39^{\mathrm{ab}}$ \\
\hline Prolactin (ng/L) & $9.94 \pm 0.091^{\mathrm{ab}}$ & $10.49 \pm 0.52^{\mathrm{a}}$ & $8.40 \pm 0.57^{\mathrm{d}}$ & $8.89 \pm 0.92^{\mathrm{cd}}$ & $8.90 \pm 0.01^{\mathrm{cd}}$ & $9.46 \pm 0.73^{b c}$ \\
\hline
\end{tabular}

$a, b, c$ and $d:$ Means of each parameter with different superscripts are significantly different $(P<0.05)$.

$G_{1}$, fed $100 \% \mathrm{NRC}, \mathrm{G}_{2}$ and $\mathrm{G}_{3}$ fed $100 \%$ and $120 \%$ of Shehata allowances, respectively. 
Table (7). Average body weight (BW), average daily gain (ADG) of milking and suckling Baladi cows fed on three levels of requirements and weight of their calves.

\begin{tabular}{|c|c|c|c|c|c|c|}
\hline \multirow{3}{*}{ Item } & \multicolumn{6}{|c|}{ Experimental groups } \\
\hline & \multicolumn{2}{|c|}{$\mathrm{G}_{1}$} & \multicolumn{2}{|c|}{$\mathrm{G}_{2}$} & \multicolumn{2}{|c|}{$\mathrm{G}_{3}$} \\
\hline & Milking & Suckling & Milking & Suckling & Milking & Suckling \\
\hline $\mathrm{BW}$ at calving & $377.25 \pm 3.69^{\mathrm{b}}$ & $377.50 \pm 9.13^{\mathrm{b}}$ & $380.50 \pm 8.91^{b}$ & $380.00 \pm 5.97^{b}$ & $406.00 \pm 2.38^{a}$ & $405.00 \pm 7.05^{\mathrm{a}}$ \\
\hline $\mathrm{BW}$ at end of lactation & $395.25 \pm 8.54^{\mathrm{bc}}$ & $398.75 \pm 7.80^{\mathrm{b}}$ & $385.75 \pm 4.19^{d}$ & $387.50 \pm 2.65^{\mathrm{cd}}$ & $420.00 \pm 5.35^{\mathrm{a}}$ & $426.25 \pm 1.50^{\mathrm{a}}$ \\
\hline $\operatorname{ADG}(\mathrm{kg} / \mathrm{d})$ & $0.120 \pm 0.037^{\mathrm{ab}}$ & $0.142 \pm 0.060^{\mathrm{a}}$ & $0.035 \pm 0.068^{c}$ & $0.050 \pm 0.025^{\mathrm{bc}}$ & $0.093 \pm 0.040^{\mathrm{abc}}$ & $0.142 \pm 0.052^{\mathrm{a}}$ \\
\hline Calves weight $(\mathrm{kg})$ at: & & & & & & \\
\hline Birth & $26.75 \pm 4.72^{\mathrm{ab}}$ & $25.25 \pm 3.77^{\mathrm{b}}$ & $29.25 \pm 1.50^{\mathrm{ab}}$ & $28.75 \pm 2.99^{\mathrm{ab}}$ & $31.25 \pm 0.96^{\mathrm{a}}$ & $30.50 \pm 1.73^{\mathrm{a}}$ \\
\hline Age of 15 weeks & $100.75 \pm 1.50^{\mathrm{bc}}$ & $104.00 \pm 2.71^{\mathrm{a}}$ & $97.00 \pm 0.82^{\mathrm{d}}$ & $98.75 \pm 0.50^{\mathrm{dc}}$ & $102.50 \pm 0.58^{\mathrm{ab}}$ & $103.50 \pm 0.58^{a}$ \\
\hline
\end{tabular}

$a, b, c$ and $d:$ Means of each parameter with different superscripts are significantly different $(P<0.05)$.

$G_{1}$, fed $100 \% N R C, G_{2}$ and $G_{3}$ fed $100 \%$ and $120 \%$ of Shehata allowances, respectively.

Table (8). Milk production and lactation period of milking and suckling Baladi cows fed on three levels of requirements.

\begin{tabular}{|c|c|c|c|c|c|c|}
\hline \multirow{3}{*}{ Item } & \multicolumn{6}{|c|}{ Experimental groups } \\
\hline & \multicolumn{2}{|c|}{$\mathrm{G}_{1}$} & \multicolumn{2}{|c|}{$\mathrm{G}_{2}$} & \multicolumn{2}{|c|}{$\mathrm{G}_{3}$} \\
\hline & Milking & Suckling & Milking & Suckling & Milking & Suckling \\
\hline Daily milk yield (Kg) & $5.65 \pm 1.06^{\mathrm{b}}$ & $6.53 \pm 0.96^{\mathrm{a}}$ & $4.36 \pm 1.08^{c}$ & $5.23 \pm 1.14^{\mathrm{b}}$ & $5.10 \pm 1.27^{\mathrm{b}}$ & $5.61 \pm 1.185^{b}$ \\
\hline $4 \%$ FCM $(\mathrm{Kg})$ & $5.51 \pm 1.04^{\mathrm{ab}}$ & $6.16 \pm 0.91^{\mathrm{a}}$ & $4.25 \pm 1.05^{\mathrm{c}}$ & $4.94 \pm 1.08^{b}$ & $4.98 \pm 1.24^{b}$ & $5.30 \pm 1.12^{\mathrm{b}}$ \\
\hline Total milk yield (Kg) & $834.79 \pm 173.24^{\mathrm{b}}$ & $1121.53 \pm 166.13^{a}$ & $485.05 \pm 119.73^{\mathrm{d}}$ & $615.83 \pm 165.55^{\mathrm{c}}$ & $646.43 \pm 179.26^{c}$ & $880.77 \pm 189.64^{b}$ \\
\hline Total 4 \% FCM $(\mathrm{Kg})$ & $814.10 \pm 169.08^{b}$ & $1057.98 \pm 156.91^{\mathrm{a}}$ & $472.81 \pm 116.85^{\mathrm{d}}$ & $581.69 \pm 156.37^{\mathrm{c}}$ & $631.22 \pm 174.96^{c}$ & $832.10 \pm 179.12^{b}$ \\
\hline Days of lactation & $147.75 \pm 13.82^{\mathrm{ab}}$ & $171.75 \pm 14.71^{\mathrm{a}}$ & $111.25 \pm 17.00^{\mathrm{c}}$ & $137.75 \pm 11.70^{\mathrm{bc}}$ & $126.75 \pm 21.31^{b c}$ & $157.00 \pm 18.51^{\mathrm{a}}$ \\
\hline
\end{tabular}

$a, b, c$ and $d:$ Means of each parameter with different superscripts are significantly different $(P<0.05)$.

$G_{1}$, fed $100 \% \mathrm{NRC}, \mathrm{G}_{2}$ and $\mathrm{G}_{3}$ fed $100 \%$ and $120 \%$ of Shehata allowances, respectively. 
Egyptian J. Nutrition and Feeds (2015)

Table (9). Milk composition and somatic cell count (SCC) in milking and suckling Baladi cows fed on three levels of requirements.

\begin{tabular}{|c|c|c|c|c|c|c|}
\hline \multirow{3}{*}{ Item } & \multicolumn{6}{|c|}{ Experimental groups } \\
\hline & \multicolumn{2}{|c|}{$\mathrm{G}_{1}$} & \multicolumn{2}{|c|}{$\mathrm{G}_{2}$} & \multicolumn{2}{|c|}{$\mathrm{G}_{3}$} \\
\hline & Milking & Suckling & Milking & Suckling & Milking & Suckling \\
\hline Fat $(\%)$ & $3.37 \pm 0.19$ & $3.28 \pm 0.21$ & $3.63 \pm 0.26$ & $3.59 \pm 0.26$ & $3.46 \pm 0.26$ & $3.42 \pm 0.12$ \\
\hline Fat yield (kg) & $0.19 \pm 0.04^{b}$ & $0.21 \pm 0.03^{\mathrm{a}}$ & $0.16 \pm 0.04^{\mathrm{c}}$ & $0.19 \pm 0.04^{b}$ & $0.18 \pm 0.04 b^{c}$ & $0.19 \pm 0.04^{\mathrm{b}}$ \\
\hline Protein $(\%)$ & $3.13 \pm 0.22$ & $3.12 \pm 0.08$ & $3.39 \pm 0.28$ & $3.29 \pm 0.36$ & $3.35 \pm 0.30$ & $3.17 \pm 0.35$ \\
\hline Protein yield (kg) & $0.18 \pm 0.03^{b}$ & $0.20 \pm 0.03^{\mathrm{a}}$ & $0.15 \pm 0.04^{\mathrm{c}}$ & $0.17 \pm 0.03^{b}$ & $0.17 \pm 0.04^{\mathrm{bc}}$ & $0.18 \pm 0.04^{b}$ \\
\hline Lactose $(\%)$ & $3.97 \pm 0.59$ & $4.34 \pm 0.61$ & $4.44 \pm 0.45$ & $4.13 \pm 0.78$ & $4.33 \pm 0.69$ & $4.60 \pm 0.54$ \\
\hline $\mathrm{SCC}\left(\mathrm{n} \times 10^{3} / \mathrm{ml}\right)$ & $507.50 \pm 14.67^{\mathrm{a}}$ & $489.00 \pm 12.83^{\mathrm{b}}$ & $498.00 \pm 8.52^{\mathrm{ab}}$ & $471.50 \pm 8.89^{c}$ & $504.38 \pm 14.50^{\mathrm{a}}$ & $485.00 \pm 13.92^{\mathrm{b}}$ \\
\hline
\end{tabular}

$a$ and $b:$ Means of each parameter with different superscripts are significantly different $(P<0.05)$.

$G_{1}$, fed $100 \% \mathrm{NRC}, \mathrm{G}_{2}$ and $\mathrm{G}_{3}$ fed $100 \%$ and $120 \%$ of Shehata allowances, respectively.

Table (10). Reproductive performance of milking and suckling Baladi cows fed on three levels of requirements.

\begin{tabular}{|c|c|c|c|c|c|c|}
\hline \multirow{3}{*}{ Item } & \multicolumn{6}{|c|}{ experimental groups } \\
\hline & \multicolumn{2}{|c|}{$\mathrm{G}_{1}$} & \multicolumn{2}{|c|}{$\mathrm{G}_{2}$} & \multicolumn{2}{|c|}{$\mathrm{G}_{3}$} \\
\hline & Milking & Suckling & Milking & Suckling & Milking & Suckling \\
\hline Days of maximum P4 level & $13.50 \pm 0.58^{\mathrm{ab}}$ & $14.25 \pm 0.50^{\mathrm{a}}$ & $11.50 \pm 0.58^{\mathrm{d}}$ & $12.25 \pm 0.50^{\mathrm{cd}}$ & $13.00 \pm 0.82^{\mathrm{bc}}$ & $13.25 \pm 0.50^{\mathrm{b}}$ \\
\hline Value of maximum P4 level (ng/ml) & $6.50 \pm 0.22^{\mathrm{c}}$ & $6.28 \pm 0.17^{\mathrm{c}}$ & $7.45 \pm 0.13^{\mathrm{a}}$ & $6.90 \pm 0.08^{\mathrm{b}}$ & $6.88 \pm 0.17^{\mathrm{b}}$ & $6.25 \pm 0.24^{\mathrm{c}}$ \\
\hline Day to reach $\geq 1.0(\mathrm{ng} / \mathrm{ml})$ & $4.50 \pm 0.58^{\mathrm{a}}$ & $4.75 \pm 0.50^{\mathrm{a}}$ & $3.25 \pm 0.50^{\mathrm{b}}$ & $4.00 \pm 0.82^{\mathrm{ab}}$ & $4.25 \pm 0.96^{\mathrm{ab}}$ & $4.50 \pm 0.58^{\mathrm{a}}$ \\
\hline Uterine involution period (day) & $27.00 \pm 0.82^{\mathrm{b}}$ & $29.75 \pm 1.71^{\mathrm{a}}$ & $21.00 \pm 0.82^{\mathrm{d}}$ & $23.00 \pm 0.82^{c}$ & $25.75 \pm 0.96^{\mathrm{b}}$ & $26.75 \pm 0.96^{b}$ \\
\hline First ovulation (day) & $30.50 \pm 0.58^{b}$ & $33.00 \pm 1.41^{\mathrm{a}}$ & $24.25 \pm 0.50^{\mathrm{d}}$ & $26.25 \pm 1.26^{\mathrm{c}}$ & $29.25 \pm 1.26^{\mathrm{b}}$ & $30.25 \pm 1.50^{b}$ \\
\hline First estrus, day & $41.00 \pm 0.82^{\mathrm{b}}$ & $43.25 \pm 1.26^{\mathrm{a}}$ & $34.25 \pm 0.50^{\mathrm{d}}$ & $36.50 \pm 1.29^{c}$ & $40.00 \pm 1.41^{\mathrm{b}}$ & $41.25 \pm 1.50^{\mathrm{b}}$ \\
\hline First service, day & $67.50 \pm 0.58^{b}$ & $71.50 \pm 1.29^{\mathrm{a}}$ & $56.50 \pm 1.29^{\mathrm{e}}$ & $60.00 \pm 1.41^{\mathrm{d}}$ & $65.25 \pm 1.26^{\mathrm{c}}$ & $69.00 \pm 1.15^{\mathrm{b}}$ \\
\hline Service period, day & $65.00 \pm 0.82^{\mathrm{b}}$ & $67.50 \pm 1.29^{\mathrm{a}}$ & $46.25 \pm 1.50^{\mathrm{f}}$ & $48.50 \pm 1.29^{\mathrm{e}}$ & $59.50 \pm 0.58^{d}$ & $62.50 \pm 0.58^{c}$ \\
\hline Days open, day & $132.50 \pm 1.00^{\mathrm{b}}$ & $139.00 \pm 2.58^{\mathrm{a}}$ & $102.75 \pm 2.75^{\mathrm{e}}$ & $108.50 \pm 2.52^{\mathrm{d}}$ & $124.75 \pm 1.71^{\mathrm{c}}$ & $131.50 \pm 1.73^{\mathrm{b}}$ \\
\hline Number of services per conception & $3.25 \pm 0.50^{\mathrm{a}}$ & $3.50 \pm 0.58^{\mathrm{a}}$ & $1.75 \pm 0.50^{\mathrm{c}}$ & $2.25 \pm 0.50^{\mathrm{bc}}$ & $2.75 \pm 0.50^{\mathrm{ab}}$ & $3.00 \pm 0.82^{\mathrm{ab}}$ \\
\hline
\end{tabular}

$a$ and $b$ : Means of each parameter with different superscripts are significantly different $(P<0.05)$.

$G_{l}$, fed $100 \% \mathrm{NRC}, G_{2}$ and $G_{3}$ fed $100 \%$ and $120 \%$ of Shehata allowances, respectively. 

Table (11). Economic evaluation of the milking and suckling Baladi cows fed on three levels of requirements at the end of the lactation period.

\begin{tabular}{|c|c|c|c|c|c|c|}
\hline \multirow{3}{*}{ Items } & \multicolumn{6}{|c|}{ experimental groups } \\
\hline & \multicolumn{2}{|c|}{$\mathrm{G}_{1}$} & \multicolumn{2}{|c|}{$\mathrm{G}_{2}$} & \multicolumn{2}{|c|}{$\mathrm{G}_{3}$} \\
\hline & Milking & Suckling & Milking & Suckling & Milking & Suckling \\
\hline \multicolumn{7}{|l|}{$\begin{array}{l}\text { Daily DM intake } \\
(\mathrm{Kg}):\end{array}$} \\
\hline CFM & $4.53 \pm 0.79^{a}$ & $4.96 \pm 0.53^{\mathrm{a}}$ & $2.82 \pm 0.11^{\mathrm{c}}$ & $2.73 \pm 0.31^{\mathrm{c}}$ & $3.82 \pm 0.30^{\mathrm{b}}$ & $3.77 \pm 0.40^{\mathrm{b}}$ \\
\hline Clover hay & $2.85 \pm 0.18^{\mathrm{a}}$ & $2.86 \pm 0.16^{\mathrm{a}}$ & $2.08 \pm 0.17^{\mathrm{b}}$ & $2.29 \pm 0.13^{\mathrm{b}}$ & $2.70 \pm 0.23^{\mathrm{a}}$ & $2.96 \pm 0.35^{\mathrm{a}}$ \\
\hline Rice straw & $2.09 \pm 0.52^{\mathrm{bc}}$ & $2.09 \pm 0.50^{\mathrm{bc}}$ & $1.91 \pm 0.18^{\mathrm{c}}$ & $2.43 \pm 0.33^{\mathrm{abc}}$ & $2.82 \pm 0.18^{a}$ & $2.55 \pm 0.43^{\mathrm{ab}}$ \\
\hline $\begin{array}{l}\text { Total DM intake } \\
(\mathrm{Kg} / \mathrm{h} / \mathrm{d})\end{array}$ & $9.47 \pm 0.38^{\mathrm{a}}$ & $9.91 \pm 0.39^{a}$ & $6.81 \pm 0.39^{\mathrm{b}}$ & $7.45 \pm 0.74^{\mathrm{b}}$ & $9.34 \pm 0.39^{\mathrm{a}}$ & $9.28 \pm 0.78^{\mathrm{a}}$ \\
\hline $\begin{array}{l}\text { Diet cost/cow/day, } \\
\text { LE }\end{array}$ & 16.15 & 17.24 & 10.73 & 11.02 & 14.49 & 14.59 \\
\hline $\begin{array}{l}\text { lactation period, } \\
\text { day }\end{array}$ & 147.75 & 171.75 & 111.25 & 137.75 & 126.75 & 157.00 \\
\hline $\begin{array}{l}\text { Diet cost/cow } \\
\text { /lactation period, } \\
\mathrm{LE}^{(1)}\end{array}$ & 2386.16 & 2960.97 & 1193.71 & 1518.01 & 1836.61 & 2290.63 \\
\hline Daily milk yield, kg & $5.65 \pm 1.06^{\mathrm{b}}$ & $6.53 \pm 0.96^{\mathrm{a}}$ & $4.36 \pm 1.08^{c}$ & $5.23 \pm 1.14^{\mathrm{b}}$ & $5.10 \pm 1.27^{\mathrm{b}}$ & $5.61 \pm 1.185^{\mathrm{b}}$ \\
\hline $\begin{array}{l}\text { Price of milk } \\
\text { yield/cow/day, LE } \\
\text { (2) }\end{array}$ & 19.78 & 22.86 & 15.26 & 18.31 & 17.85 & 19.64 \\
\hline $\begin{array}{l}\text { Price of milk } \\
\text { yield/cow/ lactation } \\
\text { period, LE }{ }^{(3)}\end{array}$ & 2922.50 & 3926.21 & 1697.68 & 2522.20 & 2262.49 & 3083.48 \\
\hline $\begin{array}{l}\text { Profit above } \\
\text { feeding cost, LE }\end{array}$ & 536.34 & 965.24 & 503.97 & 1004.19 & 425.88 & 792.85 \\
\hline \multicolumn{7}{|c|}{$\begin{array}{l}\text { Price of one } \mathrm{kg} \text { (DM basis) of concentrate feed mixture (CFM), clover hay and rice straw were LE 2.52, } 1.33 \text { and } \\
0.45 \text {, respectively. These prices estimated in } 2014 \text {. }\end{array}$} \\
\hline
\end{tabular}




\section{أحمد محمد عبد الحفيظ، ممدوح علي السيد علي، عبد المنعم السيد على محجوب، محمود يس محمد و سمير علي ابراهيم}

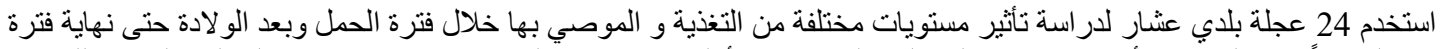

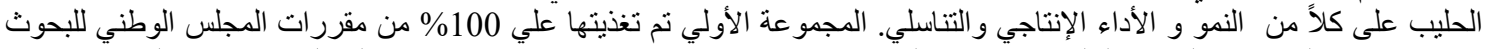

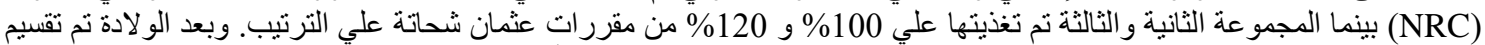

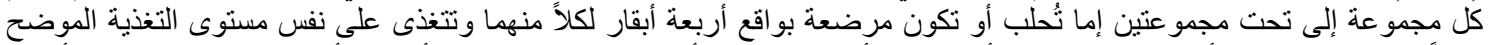

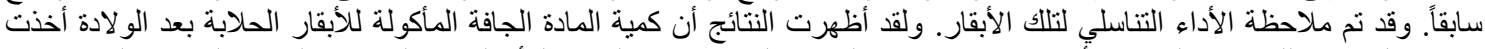

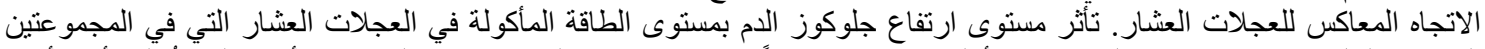

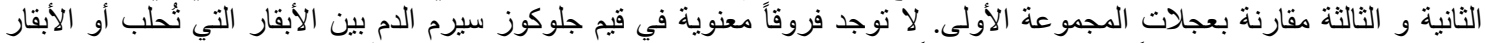

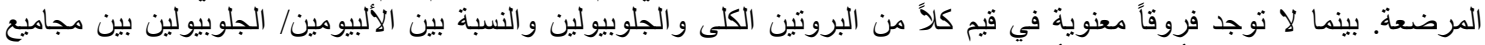

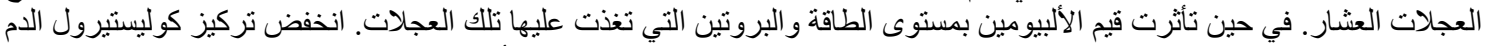

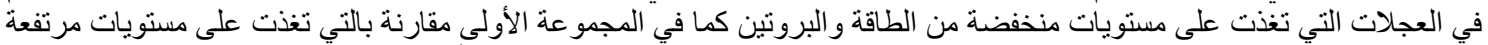

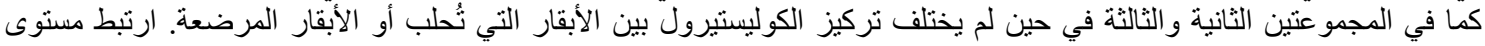

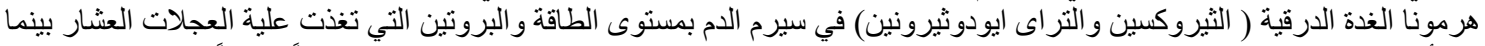

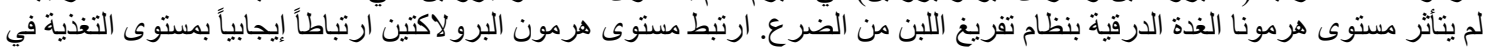

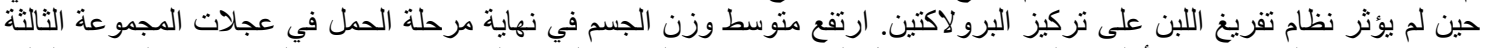

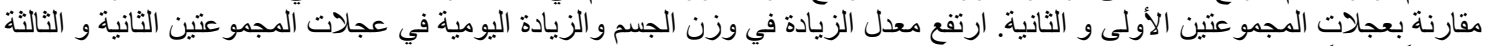

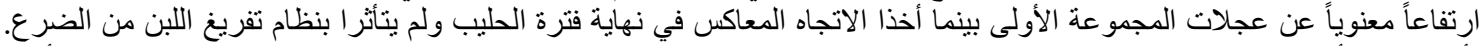

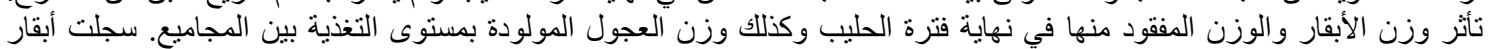

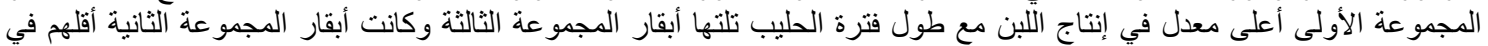

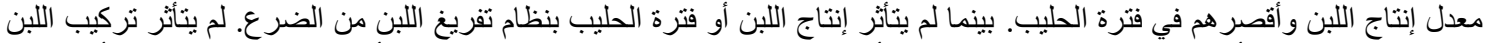

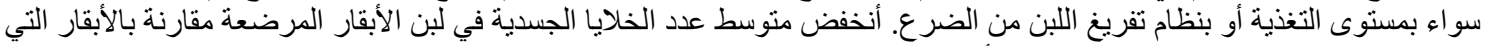

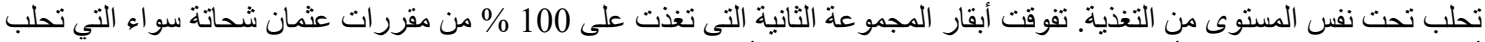

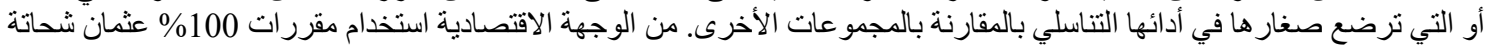

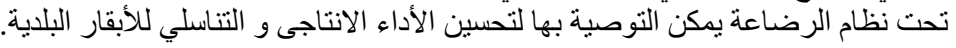

